\title{
Sprawozdanie z sympozjum Wydziału Prawa Kanonicznego Uniwersytetu Papieskiego Jana Pawła II w Krakowie pt. „Co mówić i jak mówić?” Ochrona tajemnicy, dobrego imienia oraz intymności w prawie Kościoła
} DOI: http://dx.doi.org/10.15633/acan.3833

21 listopada 2019 roku w Domu Stradomskim Zgromadzenia Księży Misjonarzy, u stóp wzgórza wawelskiego, odbyło się kolejne sympozjum organizowane przez krakowskie środowisko kanonistów z Wydziału Prawa Kanonicznego Uniwersytetu Papieskiego Jana Pawła II. Nader aktualną myśl przewodnią konferencji zarysowano w temacie „Co mówić i jak mówić?” Ochrona tajemnicy, dobrego imienia oraz intymności w prawie Kościoła", zaś obrady dotyczyły przede wszystkim szeroko pojętych zagadnień z zakresu podmiotowych praw wiernych, kościelnego prawa karnego, zadania nauczycielskiego i uświęcającego, a także prawa wyznaniowego.

Jako pierwszy głos zabrał ks. prof. dr hab. Tomasz Rozkrut - dziekan tutejszego Wydziału Prawa Kanonicznego. Dokonując tradycyjnej inauguracji wydarzenia, powiedział, że tegoroczna problematyka została zainspirowana dekretem ogólnym w sprawie ochrony osób fizycznych w związku z przetwarzaniem danych osobowych w Kościele katolickim promulgowanym 30 kwietnia 2018 r. przez Konferencję Episkopatu Polski. Ksiądz Profesor wskazał na teologiczne źródła regulacji kanonicznych w tej materii, które zakotwiczone są w biblijnej idei stworzenia człowieka na obraz i podobieństwo Najwyższego, co implikuje powszechne wezwanie do urzeczywistniania przybranego dziecięctwa Bożego. Przywoławszy słowa Jana Pawła II zawarte w encyklice Redemptor hominis z 1979 roku - że to „człowiek jest pierwszą drogą, po której winien kroczyć Kościół w wypełnianiu swojego posłannictwa" - podkreślił ewolucję spojrzenia Magisterium na prawa człowieka oraz ich zachowywanie. Następnie Ksiądz Dziekan przekazał zgromadzonym pozdrowienia od biskupów odbywających w tych dniach rekolekcje w jasnogórskim klasztorze, a także odczytał okolicznościowe listy przesłane przez kard. Stanisława Dziwisza i bp. Andrzeja Czaję. Później powitał znamienitych gości, wśród których znaleźli się reprezentanci wielu polskich ośrodków naukowych, jak również przedstawiciele instytucji kościelnych. Na zakończenie zwrócił uwagę na dwie szczególne rocznice złączone z istnieniem naszego fakultetu - 20 lat od powołania Instytutu Prawa Kanonicznego oraz 5 lat od erygowania Wydziału Prawa Kanonicznego.

Potem ks. prof. dr hab. Tomasz Rozkrut, w imieniu nieobecnego abp. Marka Jędraszewskiego - Wielkiego Kanclerza Uniwersytetu Papieskiego Jana Pawła II, przekazał pozdrowienia uczestnikom sympozjum. W skierowanym do nich słowie 
metropolita krakowski odwołał się do instrukcji Sekretariatu Stanu Secreta continere z 1974 roku, przypominając o tym, że milczenie jest sztuką niezwykle trudną, podobnie jak mówienie w sposób rozważny. Ksiądz Arcybiskup za wzór dyskrecji postawił Najświętszą Marię Pannę, która jako powierniczka wielu spraw zachowywała je i rozważała w swoim sercu.

W dalszej kolejności głos zabrał prorektor Uniwersytetu Papieskiego Jana Pawła II ds. studenckich i dydaktyki ks. dr hab. Robert Tyrała, prof. UPJPII. Jego przemówienie było swoistym wspomnieniem osoby śp. ks. prof. dr. hab. Jana Macieja Dyducha, który przed rokiem (17 listopada 2018) odszedł do Domu Ojca. Ksiądz Prorektor zaprezentował pokrótce biografię zmarłego, a także podzielił się osobistym świadectwem z ostatnich chwil Księdza Infułata, zaznaczając przy tym, że szanował on każdego człowieka oraz pomagał bliźnim w potrzebie, zaś w naszej pamięci pozostanie jako człowiek wyważonego słowa.

Pierwszą sesję prowadził prof. dr hab. Wacław Uruszczak - ceniony znawca historii prawa, wieloletni wykładowca Wydziału Prawa i Administracji Uniwersytetu Jagiellońskiego w Krakowie, komandor papieskiego Orderu Świętego Sylwestra.

Wstępny referat pt. Tajemnica duszpasterska. Czy, kiedy, i jak można żądać od duszpasterza ujawnienia informacji uzyskanych przy petnieniu posługi? składał się z dwóch części, a został wygłoszony przez pracowników Uniwersytetu Warmińsko-Mazurskiego w Olsztynie - ks. dr. hab. Lucjana Świto, prof. uwM, a także dr Małgorzatę Tomkiewicz. Ksiądz Profesor omówił przedstawione zagadnienie z perspektywy prawa kościelnego, zaczynając od podkreślenia faktu, że prywatność przynależy do elementarnych praw człowieka (pierwszej generacji). Stwierdził, że intymność podlega ochronie w systemie prawa kanonicznego, czego ogólny wyraz stanowi kan. 220 kodeksu prawa kanonicznego. Tymczasem ustawodawca kodeksowy najściślejsze zabezpieczenie przewiduje dla tajemnicy spowiedzi, która w sposób bezwzględny zakazuje szafarzowi ujawnienia czy posługiwania się informacjami pozyskanymi od penitenta w trakcie sprawowania sakramentu pokuty i pojednania. Prelegent zauważył, że istnieją również inne formy kontaktu duchowego z wiernymi (jak rozmowa, wizyta kolędowa lub procesy małżeńskie), które jednak nie mają żadnej formy asekuracji na gruncie Kościoła katolickiego, w przeciwieństwie do regulacji obowiązujących chociażby w Kościele Ewangelicko-Augsburskim w Rzeczypospolitej Polskiej. Ksiądz Profesor na kanwie wspomnianego kan. 220 podjął próbę zdefiniowania tajemnicy duszpasterskiej, która miałaby obejmować wszelkie informacje, jakie osoba duchowna uzyskała w trakcie sprawowania posługi religijnej. Argumentował, że ochronie ma podlegać w tym 
przypadku prawo do intymności na dwóch płaszczyznach - informacji przekazanych ustnie, a zarazem dokumentów i innych nośników zawierających takowe dane, przywołując przy tej okazji obowiązek spoczywający na adwokatach, osobach zatrudnionych w trybunałach czy kuriach diecezjalnych, dotyczący zachowania sekretu pod sankcją dyscyplinarną.

Drugą część odczytu zaprezentowała dr Małgorzata Tomkiewicz, która równolegle do pracy akademickiej wyrokuje w Sądzie Okręgowym w Olsztynie. Na wstępie stwierdziła, że prawo polskie nie uznaje sekretu duszpasterskiego, nawet jako tajemnicy zawodowej, ponieważ nie wywodzi się on z żadnego kryterium doktrynalnego, na które składają się: zakotwiczenie w akcie prawnym, wynikanie $\mathrm{z}$ deontologii zawodu lub pochodzenie z umowy. Przemawiająca zaakcentowała, że konsekwencją nierozpoznawania w systemie państwowym tegoż sekretu jest brak jakiejkolwiek ochrony w procedurze karnej, cywilnej czy administracyjnej, co skutkuje np. możliwością przesłuchania depozytariusza w kwestii tego, czego dowiedział się podczas posługi religijnej. Nadto żadnej asekuracji nie podlegają dokumenty kościelne, a obiekty podmiotów konfesyjnych mogą być dowolnie przeszukiwane lub kontrolowane - chociażby na zasadzie pozyskiwania informacji przez stosowanie podsłuchu operacyjnego. Na koniec sędzia Tomkiewicz zaapelowała o pilną inicjatywę ustawodawczą, przedstawiając propozycje konkretnych postulatów de lege ferenda, z czego najbardziej ważkim wydaje się ukonstytuowanie tajemnicy duszpasterskiej jako tajemnicy zawodowej sui generis.

Kolejnym prelegentem był ks. dr hab. Tomasz Jakubiak z Papieskiego Wydziału Teologicznego św. Jana Chrzciciela w Warszawie, który wygłosił odczyt nt. Protokót przedślubny. Obowiq̨zek odpowiedzi na pytania a ochrona własnej intymności. Jako wprowadzenie Ksiądz Profesor przywołał myśl Piusa XII, który stwierdził, że intymność obejmuje cały wewnętrzny świat człowieka, niedostępny dla osób postronnych. Na podstawie tej papieskiej wypowiedzi podjął się analizy prawa do dobrego imienia, dokonując jego szerokiej wykładni, bo obejmującej takie wartości, jak honor, poważanie, reputację, szacunek, a także inne dobra, którymi beneficjent cieszy się w społeczeństwie. Następnie referujący odniósł się do normy wypływającej z kan. 223, aby wyeksplikować, że realizacja praw podmiotowych w Kościele może zostać ograniczona, co - według warszawskiego kanonisty - ma zastosowanie również względem nieochrzczonych, gdyż wskazany przepis wywodzi się z prawa Bożego pozytywnego, a skonkretyzowany został w deklaracji o wolności religijnej Dignitatis humanae Soboru Watykańskiego II. Ograniczenie to dokonać się może jedynie, gdy zachodzi wyjątkowa konieczność oraz uzasadnienie wynikające z misji 
Kościoła. Dalej Ksiądz Profesor przeszedł do omówienia instytucji protokołu przedślubnego, którego wypełnienie jest konsekwencją obowiązku przeprowadzenia badania narzeczonych (kan. 1066). Egzaminatorem powinien być wyłącznie kompetentny duszpasterz, zaś jego zadania to: pozyskanie informacji o tożsamości nupturientów, stwierdzenie wolności od przeszkód, a także wykazanie braku wad zgody, natomiast sami nupturienci mają prawną i moralną powinność szczerego odpowiadania na zadawane pytania. Jednakże w opinii przemawiającego ten obowiązek badanych nie jest absolutny, ponieważ istnieją okoliczności znoszące jego obligatoryjność, jak np. realne zagrożenie, że strona - poprzez wyjawienie jakiejś informacji - przyzna się do popełnienia przestępstwa kryminalizowanego przez prawo kanoniczne lub świeckie. Podsumowując, Ksiądz Profesor wyraził potrzebę respektowania prawa do intymności w praktyce kancelaryjnej, a zwłaszcza podczas procesu rozeznania.

Referat Homilia i przepowiadanie. Jak dzisiaj głosić prawdę, nie naruszając dobrego imienia? kończący pierwszą sesję przedstawił ks. dr hab. Piotr Kroczek, prof. UPJPII - reprezentant Wydziału Prawa Kanonicznego Uniwersytetu Papieskiego Jana Pawła II oraz Kościelny Inspektor Ochrony Danych. Ksiądz Profesor podkreślił, że Kościół ma usankcjonowany kanonicznie obowiązek głoszenia słowa Bożego, w którego realizowaniu winno uwzględniać się prawno-naturalną normę kan. 22o. Dodał, że na podstawie obowiązujących regulacji treści kaznodziejskie nie podlegają władztwu państwowemu tylko w zakresie tego, co dotyczy kwestii dogmatycznych oraz moralnych - poza tymi granicami prawo polskie gwarantuje każdemu prawo do ochrony dobrego imienia na gruncie karnym (zniesławienie art. 212 k.k.), a także cywilnym (naruszenie dóbr osobistych - art. 23 k.c.), dlatego nieroztropny kaznodzieja może popełnić przestępstwo lub delikt cywilny. Prelegent zaznaczył, że wspólnym punktem obu porządków prawnych jest aksjologiczne uzasadnienie przepisów w tej materii, które opierają się na wrodzonej oraz nienaruszalnej godności człowieka (uzupełnionej w systemie kanonicznym o aspekt nadprzyrodzoności). Inspektor Danych Osobowych z ramienia Konferencji Episkopatu Polski konkludował, że odpowiedzialne kaznodziejstwo powinno respektować te wartości, a także dotyczyć jedynie tego, co wpisuje się w misję Kościoła.

Panel zakończył się żywą dyskusją, bowiem największe kontrowersje wśród publiczności wywołał odczyt dr Małgorzaty Tomkiewicz. Zgromadzeni goście wyrazili nadzieję na rychłą zmianę przepisów, która doprowadzi do ukonstytuowania w prawie państwowym tajemnicy zawodowej duchownych. Prelegentka, odpowiadając na jedno z pytań, dodała ciekawą uwagę, że postulowany sekret 
duszpasterski miałby w pierwszej mierze chronić komfort wiernych korzystających z posług religijnych, a nie być postrzegany jako dodatkowy przywilej dla księży.

Kolejną sesję, rozpoczętą po półgodzinnej przerwie kawowej, pierwotnie miał moderować ks. prof. dr hab. Józef Krzywda cM, obchodzący w tym roku złoty jubileusz święceń kapłańskich, jednakże Szacowny Jubilat scedował ów przywilej na przybyłego z Lublina ks. dr. hab. Ambrożego Skorupę SDS, prof. KUL, który podjął się tego obowiązku z nieukrywaną przyjemnością.

Pierwszy referat drugiego panelu nt. Obowiq̨zek powiadomienia o przestępstwie w prawie i praktyce Kościoła zaprezentował o. dr hab. Dariusz Borek ocarm, prof. UKSW z warszawskiego Uniwersytetu Kardynała Stefana Wyszyńskiego. Mówca zaznaczył, że kan. 1311 statuuje wrodzone oraz własne prawo Ludu Bożego do karania wiernych popełniających przestępstwa, zaś władza ta wywodzi się ze słów Pana Jezusa ujętych w Ewangelii św. Mateusza (Mt 18, 5). Później przeszedł do omówienia trzech rodzajów denuncjacji rozróżnianych przez kodeks Pio-Benedyktyński, a były to: doniesienie ewangeliczne (skierowane do przełożonego jako do ojca), kanoniczne (obowiązek powiadomienia zwierzchnika, aby zainterweniował na mocy powierzonej mu władzy), a także sądowe (będące impulsem do rozpoczęcia postępowania dyscyplinarnego). Ojciec Profesor, rozważając obecność w kodyfikacji Jana Pawła II instytucji obligatoryjnej denuncjacji, doszedł do wniosku, że może ona wynikać implicite z prawnej powinności powiadomienia ordynariusza lub proboszcza o ewentualnych przeszkodach czy nieprawidłowościach (z których duża część to przestępstwa) kandydata do przyjęcia sakramentu święceń, a także wyjawienia znanych przeszkód małżeńskich nupturientów. Jako przykład najnowszych regulacji kanonicznych w tej materii przywołał instrukcję Kongregacji Kultu Bożego i Dyscypliny Sakramentów Redemptionis sacramentum z 2004 roku, normy Kongregacji Nauki Wiary De gravioribus delictis z 2010 roku, motu proprio Ojca Świętego Franciszka Vos estis lux mundi z 2019 roku oraz inne dwa akty prawne przeznaczone do wewnętrznego użytku Państwa Watykańskiego. Prelegent, na zakończenie, podjął się interpretacji obowiązku wprowadzonego do polskiego porządku prawnego ustawą z 13 lipca 2017 roku dotyczącą informowania organów państwowych o możliwym popełnieniu przestępstwa ściganego z urzędu (w kontekście czynności seksualnych z małoletnimi), jasno stwierdzając, że należy przyjąć wykładnię korzystniejszą dla ofiary.

Ostatni odczyt pt. Jawni grzesznicy. Czy zasadne jest ich publiczne piętnowanie? został przedstawiony przez o. prof. dr. hab. Wiesława Bara of Mconv z Katolickiego Uniwersytetu Lubelskiego. Na wstępie swojego wystąpienia dokonał analizy 
semantycznej pierwszego członu tematu, wykazując, że w języku starocerkiewnym ma on dwojakie znaczenie, bowiem z jednej strony publiczny grzech wywołuje wstyd u winowajcy, a z drugiej sieje zamęt oraz zgorszenie wśród innych ludzi. Następnie Ojciec Profesor stwierdził, że aby dany czyn mógł zostać zakwalifikowany jako peccatum manifestum, winien spełniać ogólne znamiona przestępstwa kanonicznego uzupełnione o wskazania Katechizmu Kościoła Katolickiego odnośnie do moralności aktów ludzkich, a także zostać przypisany jako taki na drodze obiektywnej oceny. Przypominał przy tej okazji, że na mocy kan. 209 § 1 każdy katolik jest zobowiązany do zachowania pełnej wspólnoty z Kościołem, co wyraża się chociażby przez regularne uczestnictwo w niedzielnej Mszy Świętej. Nadto przemawiający odniósł się do kan. 915, który - z racji niejasności - stał się przedmiotem deklaracji Papieskiej Rady ds. Tekstów Prawnych z 2000 roku, argumentując również, że szafarz ma prawo odmówić udzielenia Komunii Świętej wiernemu permanentnie trwającemu w jawnym grzechu ciężkim, gdyż - jak pisał Benedykt XIV - niegodziwe przyjęcie Ciała Pańskiego nie ochroni go przed osądem Chrystusa, lecz obciąży.

Po zaprezentowaniu wszystkich referatów w drugiej sesji jej przewodniczący rozpoczął dyskusję, podczas której publiczność miała możliwość zadawania pytań, a dotyczyły one przede wszystkim wątpliwości interpretacyjnych przepisów $\mathrm{z}$ dokumentu Vos estis lux mundi.

Podsumowania i zakończenia obrad dokonał ks. prof. dr hab. Tomasz Rozkrut. Wyraził nadzieję, że tegoroczne spotkanie stanie się impulsem do zmian w prawie, a także powiedział, iż w historii zapisze się ono jako szóste sympozjum Wydziału Prawa Kanonicznego Uniwersytetu Papieskiego Jana Pawła II.

Mateusz Sajkowski 